Ruth Zuzovsky

Kibbutzim College of Education, Israel

E-MAIL: ruth.zuzovsky@smkb.ac.il

Smadar Donitsa-Schmidt

Kibbutzim College of Education, Israel

E-MAIL: smadar.donitsa@smkb.ac.il

\title{
Professionalization and Professionalism of Teaching and Teachers in Israel
}

\begin{abstract}
SUMMARY
The paper describes the main national-level policy actions and initiatives taken over four decades, from the $198 \mathrm{os}$ to the present, to promote the professionalization of teaching in Israel and enhance the professionalism of Israeli teachers. It also includes a critical reflection on the success of these measures.

KEYWORDS: professionalization, professionalism, policy actions, teachers, teaching in Israel, professional development
\end{abstract}

\section{Introduction}

There have been major changes in the Israeli education system over the last four decades. Many of these changes aimed to enhance the professionalization of teaching and the professionalism of Israel's teaching force. The current paper reviews the national policy actions taken to achieve this purpose and discusses the extent to which they have been successful.

Professionalization stands for the collective effort of professional groups to formulate the terms and practices of their profession towards attaining legitimization and self-governance. The process aims to upgrade the status of the profession and seek further resources for the involved group (Goodson, 2000; Hargreaves, 2000). The professionalization of teaching might comprise extending the training duration, acquiring certificates, setting professional standards, and advocating the academization of the profession.

The term professionalism has been contested and reinterpreted over the years in response to public discourse and social studies (Evans, 2008; Evetts, 2013). It nevertheless remains related to the quality of the actions taken by individual members of a professional group, the combination between their professional commitments and their knowledge, collegial relationships with 
their peers, and their ethical relationship with their clients (Goodson, 2000; Hargreaves, 2000). Professionalism focuses on the competence, qualifications and acquired capacities required to pursue a given profession and is largely dependent on professional development throughout one's career. To ensure quality, teachers must be committed to learning throughout and beyond their life work at school (Schuepbach, 2016). While professionalization and professionalism may be in harmony, in some cases they are not, as intensive professionalization does not always guarantee greater professionalism (Hargreaves, 2000; Sachs, 2016).

Policy actions aimed at promoting the professionalization of teaching in Israel have been mostly governed by national governmental bodies. They have concentrated on prolonging teacher educational training programs, setting professional standards, pushing for further academization of the teaching profession, and improving the teachers' salaries and working conditions. Policy actions aimed at improving the professionalism of teachers have focused mainly on offering them a variety of continuing professional development activities and opportunities for lifelong learning.

\section{Professionalization of teaching and professionalism of teachers in Israel}

Teachers in Israel at all levels of education are civil servants who perform their duties under fixed-term contracts, which are set by the Israeli Government and agreed upon by the teacher unions. Israeli teachers teach in an education system that consists of four tiers: pre-primary education (ages 3-6), primary education (grades 1-6, approximately ages 6-12), lower secondary education (grades 7-9, approximately, ages 13-15) and upper secondary education (grades 10-12, approximately ages 16-18) (Zuzovsky \& Donitsa-Schmidt, 2004).

Several policy actions have been taken to enhance the professionalization of teaching and the professionalism of teachers in Israel. The most pivotal has been the academization of the teachers' education institutions, which began in the 1980s. Two bodies governed the process - the Ministry of Education and the Council for Higher Education, The Ministry of Education, founded in 1949, one year after the establishment of the State of Israel oversees public education in Israel including its institutions, curricula and teacher training. The Council for Higher Education, established under law in 1958, is an independent and autonomous official authority that is responsible for higher education in Israel and determines its policy. The first and most seminal stage in 
the academization process was a gradual upgrading of teacher seminaries to academic colleges. Under the guidelines of the Council for Higher Education (Dan Committee, 1981), the duration of teacher training was extended from two or three years to four-year programs awarding a Bachelor of Education (B.Ed.) degree and a teaching certificate (Dror, 2013).

The second milestone in the academization process occurred in 2004, when the Council for Higher Education granted teacher colleges permission to open two-year post-qualification Masters' in Education programs for practicing teachers (M.Ed.). This move was in line with the continuous efforts made by the Ministry of Education to elevate the status of the teaching profession. Yet, under the pressure of the universities that insisted on maintaining their hegemony as research institutions, the Council for Higher Education approved teacher-education colleges to open post-graduate study tracks that did not include research. Only in 2012 was a research track added, signaling another landmark in the professionalization of teaching but also to teachers' professionalism. Another way to enhance the teaching force professionalism was the opening of Master of Teaching programs (Mteach) in 2010, combining a post-graduate certificate in education (PGCE) and a master's degree in education (Zuzovsky, Donitsa-Schmidt, Trumper, Arar \& Barak, 2019).

In 2006, two years after the launching of the post-qualification master's programs in teacher colleges, a committee of the Council for Higher Education published a uniform set of guidelines for all teacher education institutions (Ariav Committee, 2006). The guidelines laid out a template for initial and continuous teachers training programs, defining the required study components and the study hours to be allocated to each. The committee placed special emphasis on disciplinary studies and gave them greater weight. Over the years, along with the academization of teacher education programs, the required qualifications of college faculty members have also been raised (Hofman \& Niederland, 2012).

In 2003, the Israeli government appointed the famous Dovrat Committee, also known as the National Task Force for the Advancement of Education in Israel, to inspect the professionalization of teaching and the teachers' professionalism. The committee was largely appointed in response to public criticism against the Israeli education system and its achievements, which put much of the blame on the teachers. The committee members included leading figures from the fields of economy, administration, and education, but no representatives of the colleges of education or the two teachers' unions. In early 2005, the Dovrat committee recommended making changes to the job structure, workload and salaries of teachers, to raise the status of the teach- 
ing profession. It also recommended making structural, organizational and pedagogical changes to the teacher education system (Blass, 2012).

Following the Dovrat Committee recommendations, two major reforms were launched: at the primary school level in 2008 ('New Horizon' reform) and at the secondary school level in 2012 ('Courage to Change' reform). This time, the teacher unions were actively involved in putting together the collective agreements, which included a substantial raise in teachers' salaries and improving their working conditions. A new promotion scale was defined, linking teachers' promotion to their participation in professional development activities. Several additional administrative and structural changes were made (Blass, 2016). The most notable ones were the establishment of two new bodies: RAMA, an independent National Authority for Measurement and Evaluation in Education (Beller, 2013) and 'Avney Rosha' Institute for training school principals (Shaked, 2014). Another important outcome of the Dovrat Committee recommendations was that the colleges of education gradually came under full auspices of the Council for Higher Education, including budgeting. This has allowed teacher colleges greater autonomy in handling their academic and administrative affairs. Consequently, small colleges have merged to create larger university-type institutions. Following these mergers, the number of colleges went down from 26 in 2000 to 21 in 2020 with further aims to reduce their number to eight in the future (Blass, 2016).

The Ministry of Education, viewing the teachers' education as an ongoing lifelong process, decided in 2013 to restructure the department in charge of the entire teaching force, and split it into three subdepartments, each responsible for a different phase in the teachers' careers: initial teacher training (pre-service), induction years, and continuous professional development (in-service).

The professional development options currently offered to practicing teachers include a variety of learning opportunities such as school-based activities, in-service courses given at regional teacher centers and colleges2, learner communities guided by teacher leaders (Avidov-Ungar \& Reingold, 2018), massive open online courses (MOOCS) ${ }^{3}$, diploma certification studies, and studies towards advanced academic degrees (Zuzovsky, Donitsa-Schmidt,

2 See for example information on the website of the Ministry of Education's English teaching inspectorate: https://cms.education.gov.il/educationcms/units/mazkirut_pedagogit/english/inspectoratesdesk/, [retrieved: November 29, 2020].

3 The Campus IL project is a free digital learning platform that offers massive open online courses in a wide range of topics. It was established as a joint initiative of the National Israel Digital Project at the Ministry of Social Equality and the Council for Higher Education in 2015 - https://campus.gov.il/en/, [retrieved: November $29^{\text {th }}, 2020$ ]. 
Trumper, Arar \& Barak, 2019). This assortment is expected to meet the diverse needs of individual teachers as well as promote educational and professional changes in the school system. To avoid eclectic professional development, the school principal has been put in charge of designing tailor-made three-year continuing professional development programs for each teacher, compatible with teachers' needs and the school's goals and requirements and pending the approval of the regional supervisor. As already noted, since the two major school reforms of 2008 and 2013, a direct link has existed between the teachers' continuous professional development, their career ladder, and their salary (Blass, 2016). In-service activities grant teachers credit points that accumulate over the years and are translated into salary raises. This could explain the fact that $86 \%$ of the teachers study in different professional development frameworks (Mikulincer \& Parzanchevsky Amir, 2020). Active professional learning is also a factor in promoting teachers on a 9-grade career scale, where the highest level is reserved to leadership positions in school.

\section{Summary and Discussion}

Although the academization of the teacher education colleges was a cardinal move towards the professionalization of teaching, it has not been fully accomplished. The status of the teaching profession is still relatively low in Israel. Compared to other OECD countries and despite two major reforms, teachers' salaries in Israel are below average and lower than those of similar professions such as nursing and social work (Blass, 2016; Central Bureau of Statistics, 2017; OECD, 2018). The working conditions of Israeli teachers are also less than attractive. Class size is one of the largest in the OECD at all school levels, and the average number of weekly working hours is slightly above the OECD average (OECD, 2018).

In an international survey of 21 countries, Israel was ranked at the bottom of the Teacher Status Index scale. The survey revealed that Israelis did not trust teachers to deliver their students quality education, and respect for teachers was the lowest among all the countries surveyed (Dolton, Marcenaro, de Vries \& She, 2018).

The low prestige of the teaching profession results in difficulty recruiting high-quality candidates to the education system and retaining them, creating a chronic shortage in teachers (Donitsa-Schmidt \& Zuzovsky, 2016). One of the strategies school principals implement to cope with this shortage is hiring teachers without appropriate qualifications. While this phenomenon, known as out-of-field teaching (Ingersoll, 1999), solves the quantitative aspect of the shortage, it creates a quality problem. According to a recent report, between 
$40 \%$ to $60 \%$ of the core school subject teachers in Israel are out-of-field teachers (State Comptroller, 2019). As the State Comptroller noted, this situation "harms the students and may cause them long-term damage in terms of the quality of the knowledge, the skill they acquire, and the scholastic achievements that follow" (State Comptroller 2019, p. 937).

Further indication of the inadequate professionalism of Israeli teachers is their insufficient knowledge. A study that reviewed empirical data on the types of knowledge Israeli teachers possesses revealed that beginner teachers lack the required content and pedagogical content knowledge. Later in their careers, Israeli teachers expressed a need for other missing types of knowledge, such as assessment literacy, technological knowledge, acquaintance with research methodology and teaching children with special needs (Donitsa-Schmidt \& Zuzovsky, 2019). Almost two decades after the Dovrat Committee recommendations, the achievements of Israeli students in international comparative studies are still slightly below the international average score (OECD, 2019).

To resolve the shortage of teachers, the Ministry of Education has initiated in the past decade several alternative paths for initial teacher training. These are usually on-the-job accelerated and condensed programs that are open to post-graduate certificate in education (PGCE) candidates who already have a strong university-based academic background. These programs aim to attract high-quality candidates into the education system. Yet, the Ministry of Education came under severe criticism for taking this course of action, accusing that such accelerated programs are causing further deterioration of the professionalization of teaching and the professionalism of teachers (Weinberger \& Donitsa-Schmidt, 2016; Donitsa-Schmidt \& Ramot, 2020).

Although efforts have been made to promote the professionalism of the teachers by offering them varied professional opportunities, recent studies have revealed that this was not achieved in full (Mikulincer \& Parzanchevsky-Amir, 2020). The policy guideline assigning school principals the task of planning teachers' professional development programs has not been implemented, hindering the long-term planning of the professional and career advancement of teachers. No official success measures have been established for assessing the quality of the professional development activities. No research was conducted to measure the effect of teachers' professional development on their teaching skills, professional identity and professional well-being, and on the achievements of their students. Too many bodies, some with conflicting agendas, are involved in the professional development activities offered to teachers. Finally, better coordination is required between the various 
national, regional, and school level stakeholders handling the professional development of teachers.

In conclusion, over the past forty years, educational policymakers have invested heavily in teaching professionalization and in enhancing Israeli teachers' professionalism. However, these processes are still underway and have not yet reached their goals. The academization process has not been finalized to date. Of twenty-one academic teacher education colleges, only three have come under full auspices of the Council for Higher Education. At the same time, first-tier research universities, keep opposing the full academization of teacher colleges, to retain their hegemony (Hofman \& Niederland, 2012). Their resistance blocks the allocation of research budgets to the colleges, impedes the promotion of teacher educators, and hinders colleges from awarding doctoral degrees.

While some researchers have noted that professionalization and professionalism do not always coexist and might even contradict one another, this is not the case in the Israeli context, where these two lines of policy actions seem to intertwine. Many policy actions aimed at one avenue have also served as springboards for the other. These complementary policy actions should continue in the coming years with the support of all the governing bodies and stakeholders involved. Since education is the acknowledged backbone of society, it is imperative that the Israeli government continue to invest in the enhancement of the teaching profession and the teaching force.

\section{REFERENCES}

Ariav Committee (2006). Report of the committee for determining outlines for teacher education in higher education institutions in Israel. Jerusalem, Israel: Council for Higher Education. [Hebrew].

Avidov-Ungar, O., Reingold, R. (2018). Israeli Ministry of Education's district managers' and superintendents' role as educational leaders - implementing the new policy for teachers' professional development. International Journal of Leadership in Education, 21(3), 293309.

Beller, M. (2013). Assessment in the service of learning: Theory and practice. Ramat Gan, Israel: RAMA: The National Authority for Measurement \& Evaluation in Education.

Blass, N. (2012). The Dovrat Committee, Ofek Hadash and Oz LeTmura: A story of rejection and acceptance. In: D. Ben-David (Ed.), The state of the nation report: Society, economy and policy in Israel 2011-2012 (pp. 331-364). Jerusalem, Israel: Taub Center for Social Policy Studies in Israel.

Blass, N. (2016). Twelve years of the national task force for the advancement of education in Israel: What has changed? In: A. Weiss (Ed.), The state of the nation Report: Society, Economy and Policy in Israel (pp. 107-147). Jerusalem, Israel: Taub Center for Social Policy Studies in Israel.

Central Bureau of Statistics (2017). Statistical almanac for Israel no. 68. Jerusalem: CBS. [Hebrew]. 
Dan Committee (1981). Guidelines for a B.Ed. degree. Jerusalem, Israel: Council for Higher Education. [Hebrew].

Dolton, P., Marcenaro, O. de Vries R., She, P. (2018). Global Teacher Status Index 2018. London, UK: The Varkey Foundations.

Donitsa-Schmidt, S., Zuzovsky, R. (2016). Quantitative and qualitative teacher shortage and the turnover phenomenon. International Journal of Educational Research, 77, 83-91.

Donitsa-Schmidt, S., Zuzovsky, R. (2019). Learning to Teach in Israel: Reviewing Policy and Research. In: M.T. Tatto, I. Menter (Eds.), Knowledge, policy and practice in teacher education: A cross-national study (pp. 117-134). London, UK: Bloomsbury Academic Publishing.

Donitsa-Schmidt, S., Ramot, R. (2020). Opportunities and challenges: teacher education in Israel in the Covid-19 pandemic. Journal of Education for Teaching, 1-10.

Dovrat Committee (2005). The National Task Force for the advancement of Education in Israel. Jerusalem, Israel: Ministry of Education. [Hebrew].

Dror, Y. (2013). Three Decades of Teacher Education in Israel and Their Impact on Professional Development of Teacher Educators. In: M. Ben-Peretz, S. Kleeman, R. Reichenberg, S. Shimoni (Eds.), Embracing the social and the creative: New scenarios for teacher education (pp. 35-56). Lanham, MD: Rowman \& Littlefield Education.

Evans, L. (2008). Professionalism, professionality and the development of education professionals. British Journal of Educational Studies, 56(1), 20-38.

Evetts, J. (2013). Professionalism: Value and ideology. Current Sociology, 61(5-6), 778-796.

Goodson, I.F. (2000). The principled professional. Prospects, 30(2), 181-188.

Hargreaves, A. (2000). Four ages of professionalism and professional learning. Teachers and teaching, 6(2), 151-182.

Hofman, A., Niederland, D. (2012). Is teacher education higher education? The politics of teacher education in Israel, 1970-2010. Higher Education Policy, 25(1), 87-106.

Ingersoll, R.M. (1999). The problem of underqualified teachers in American secondary schools. Educational Researcher, 28(2), 26-37.

Mikulincer, M., Parzanchevsky-Amir, R. (2020). Optimal management of professional development and training in the education system. Jerusalem, Israel: Yozma-Center for Knowledge and Research in Education. [Hebrew].

OECD (2018). Education at a glance: OECD indicators. Paris: OECD Publishing.

OECD (2019). PISA 2018 Results (Volume I): What Students Know and Can Do. Paris: PISA, OECD Publishing.

Sachs, J. (2016). Teacher professionalism: Why are we still talking about it? Teachers and Teaching, 22(4), 413-425.

Schuepbach, M. (2016). Extended education: Professionalization and professionalism of staff. International Journal for Research on Extended Education, 4(1), 5-8.

Shaked, H. (2014). Israel's Principal Preparation Policy. World Journal of Education, 4(6), 78-89.

State Comptroller (2019). Yearly Report 69b: Aspects in the management of teaching personnel in the education system. Jerusalem, Israel: State Comptroller's Office. [Hebrew].

Weinberger, Y., Donitsa-Schmidt, S. (2016). A longitudinal comparative study of alternative and traditional teacher education programs in Israel: Initial training, induction period, school placement, and retention rates. Educational Studies, 52(6), 552-572.

Zuzovsky, R., Donitsa-Schmidt, S. (2004). Attracting, developing and retaining effective teachers in Israel. School of Education, Science and Technology Education Center Tel-Aviv University, Tel-Aviv, Israel: OECD Country Background Report.

Zuzovsky, R., Donitsa-Schmidt, S., Trumper, R., Arar, K., Barak, J. (2019). Post-qualification master's level studies in Israel teacher colleges: A transmissive or a transformative model of professional development? Professional Development in Education, 45(4), 670-683. 